Article

\title{
Toward Science-Based and Knowledge-Based Targets for Global Sustainable Resource Use
}

\author{
Stefan Bringezu 1 \\ Center for Environmental Systems Research, University of Kassel, 34117 Kassel, Germany; \\ bringezu@uni-kassel.de
}

Received: 24 June 2019; Accepted: 28 July 2019; Published: 6 August 2019

check for updates

\begin{abstract}
The article discusses key aspects to be considered for the orientation of sustainable resource policies. Resource management at the local scale needs to be supplemented by governmental action in order to adjust production and consumption toward acceptable levels of global resource use. What is acceptable is being informed by scientific findings on environmental degradation and relevant cause-effect relationships. However, the desired state of the environment, the tolerable level of uncertainties about environmental impacts, risks of societal conflicts, and ethical considerations all involve normative considerations. Policy decisions for sustainable global resource use must be taken on the basis of imperfect information. A wider systems perspective, longer time horizon, and broader involvement of available knowledge could provide a sufficiently valid basis to derive directionally safe targets. Possible proxy targets for global biotic and abiotic resource use, considering land, biodiversity, and water issues, are presented on a per-person basis for 2050 for further discussion and research. These values could be used to assess the resource footprints of countries with regard to sustainability, providing orientation for governments and industry.
\end{abstract}

Keywords: science-based targets; socio-industrial metabolism; sustainability indicators; environmental management; resource policy

\section{Introduction}

This article addresses two main questions. (1) What can be regarded as sustainable resource on this planet? (2) How can knowledge on acceptable levels be translated into management targets?

The global extraction and processing of natural resources has accelerated over the last two decades, and accounts for more than $90 \%$ of biodiversity loss and water stress, and about half of climate change impacts [1]. Without effective policies, continuing ongoing trends, raw material use would grow from $92 \mathrm{Gt}$ in 2017 to $190 \mathrm{Gt}$ by 2060 . Greenhouse gas (GHG) emissions would increase by $43 \%$ from 2015 to 2060, industrial water withdrawals would increase by up to 100\% from 2010 levels, and the area of agricultural land would increase by more than $20 \%$, reducing forests by over $10 \%$ and habitats such as grasslands and savannahs by around $20 \%$.

There is a broad consensus that a more sustainable use of natural resources requires a profound decoupling of environmental degradation from socio-economic development, that a much higher material and energy efficiency would be required toward that end, and that this would be beneficial for both the environment and the economy [2]. However, there are still varying views on the attainable level of "absolute decoupling" and the targeted orientation level of resource use.

The use of natural resources comprises in particular abiotic and biotic materials, such as water and land. A systems approach is helpful to understand that human-induced material and water resource flows represent the input and determine the throughput of the socio-industrial metabolism; from the extraction of raw materials to the stages of manufacturing, production, consumption, and recycling 
until final disposal [3]. Land-use indicators represent land cover and include essential traits of natural and culturally shaped ecosystems, including biodiversity and ecosystem services.

There is also broad acknowledgement of the so-called "doughnut" model suggested by Raworth [4]: basic human needs require a minimum of resource supply, while the maximum of environmental pressure exerted by humans would be defined by the so-called planetary boundaries (PBs) as suggested by Rockström et al. [5,6]. However, the implementation of that concept faces four basic challenges.

Firstly, human needs tend to change and expand over time. The "basic human needs", as suggested by [7] and [4], reflect a perspective—also adopted by the United Nations Sustainable Development Goals (SDGs) - which recognizes the universal right to adequate nutrition and a worthy livelihood. With regard to the provision of adequate supply of a healthy diet for the global population, a Lancet Commission [8] recently indicated that this would rather lower than increase the pressure to the environment. However, the extension of basic facilities for sanitation to a growing world population might require more material and energy resources. Moreover, what is deemed basic facilities and equipment is changing over time, depending on the developing status of societies. For instance, nowadays in countries such as the United States (USA), televisions (TV), mobile phones, washing machines etc. are rendered basic equipment of a household, while 50 to 100 years ago, these items would have been regarded as luxuries. Since a good life is founded on many material and non-material aspects, it may be difficult to decide on universally sufficient levels of consumption in terms of specific final products, whether food items, gadgets, or even services. Moreover, it seems problematic to derive material prerequisites such as cooling and heating equipment from basic needs such as adequate housing temperature as a basis for decent living standards [9], because these basic needs may be provided by a mix of different technologies (such as energy efficient well-insulated houses). The technological realization of basic satisfiers finally determines the requirements of natural resources. When it comes to resource use, the question would be rather which resources are basically needed to supply people with adequate goods and services. The resource and carbon footprints of societies are mainly associated with basic demands of food/subsistence, housing/shelter, and transport/mobility [10,11], so that resource efficiency increases are in particular required in these fields. The relative decoupling of economic growth and resource use that is happening in many countries can be enhanced by policy to increase the overall resource efficiency of production and consumption [1]. These policies-including discussions on societal sufficiency - might be supported by absolute targets of natural resource use for the final consumption of goods and services, which are widely lacking.

Secondly, the PBs involve normative aspects. The PB approach $[5,6]$ has been a courageous attempt to bundle scientific expertise and categorize major global environmental impacts according to risk levels by defining safe, uncertain, and high risk levels of pressures to the earth systems. However, while the authors emphasize a high degree of uncertainty and the lack of evidence on the relationship between the Biodiversity Intactness Index (BII) and Earth System responses [6], they adopt BII as a preliminary indicator for biosphere integrity, setting a PB at $90 \%$ to $30 \%$. However, this implies that $10 \%$ to $70 \%$ of BII reduction could be regarded as tolerable, and that a considerable loss of species abundance, including species extinction, would seem acceptable in view of ecosystem functions. However, the question how many species should be preserved also involves societal values and can hardly be defined by scientific analysis. Moreover, adopting those suggested PBs still requires policy decisions regarding the risk level that will be tolerated by societies. Information on how those risks could be avoided by precautionary change of the use of natural resources is still largely lacking.

Thirdly, PBs have been largely defined in terms of the desired state of the environment. These are rather distant from human activities and need to be translated into actionable targets. It seems advisable to distinguish between targets of the desired state (of human health or the environment), and management targets, which are set to reach the state targets by effective action. For instance, in order to reach a desired state of a stable climate system by 2100 , the rise in global temperature should not exceed $1.5^{\circ} \mathrm{C}$. To stay within such a threshold the level of greenhouse gas (GHG) emissions registered in 2017 would have to be halved by 2030, and GHG neutrality would need to be reached by 2050 [12], 
which means a management target of net zero GHG emissions. In contrast to state targets, management targets either refer to or are closer to the pressures and driving forces (according to the Driving Forces-Pressure-State-Impact-Response (DPSIR) framework [13]) which lead to (un)desired changes of the environment.

Management indicators for the human use of natural material resources have been introduced in the first list of indicators specifying SDGs 8.4 and 12.2. Domestic material consumption (DMC) and raw material consumption (RMC), both per person and per gross domestic product (GDP), are expected to monitor progress toward decoupling economic development from material resource use. The purpose of monitoring through indicators is to enhance resource efficiency and-given state-of-the-art technology - mitigate the bundle of environmental impacts, which are linked to the extraction, use, and final disposal of raw materials. When monitored at a country level and compared with the global averages, this would already allow governments to detect whether their country is consuming global material resources above or below the world average (the latter status could be understood as "moderate sustainability" [14]). However, still, a reference is needed on the level of global resource flows, which can be deemed safely operational and could be used for orientation and the definition of targets toward "strong sustainability".

Fourthly, the attribution of a global sustainable resource use to countries ("allocation") involves ethical and legal considerations. In particular, the principles of equity and fairness come into perspective. Both can be related to the equal right to have access to the use of natural resources, and to strive for a fair share of total resource consumption. Against the background of the human rights convention, it seems rather straightforward to attribute the consumption of global resources on an equal per capita (=per person) basis to individuals and countries [15].

So far, only part of those issues have been treated in the literature. Conceptualizing to translate global PBs to national targets, Häyä et al. [16] outlined key aspects to be considered when bridging different scales: the (a) biophysical dimension, (b) socio-economic dimension, and (c) ethical dimension. While (a) relates to the environmental impacts from the global to the local level (and vice versa), (b) reflects the production-consumption system that links human activities with their interrelations with the environment, and (c) recognizes principles of equity and fairness. O'Neill et al. [17] made a brave attempt to indicate that a good life for all could be possible within planetary boundaries to serve basic needs, but for more qualitative goals such as high life satisfaction, it would require a level of resource use that is two to six times a sustainable level, assuming a direct cause-effect between resource use and life satisfaction "based on current relationships". Still, a discussion and agreement on what the authors considered as a sustainable level is lacking.

Regarding the question of how the Earth's overall limited resources should sustainably be used in terms of thresholds not to be surpassed, quantitative science-based and knowledge-based targets (SEKBTs) are required for management at national and company levels.

Based on standard methods for indicator measurement, such global resource management targets could help governments in order to

- monitor the performance of their physical economy in an internationally comparable way and in relation to a worldwide standard,

- check on their progress toward sustainability in the context of SDGs, including their fair share, and

- adjust their incentive framework for the actors in production, consumption, and infrastructures, if necessary.

For companies, such global orientation values and further derived national policy targets would also be useful in order to

- benchmark their performance of life-cycle wide or cradle-to-gate resource use in relation to national and sectoral levels, based on relations e.g., to turnover, value added, or employees,

- integrate these indicators into existing environmental management schemes (such as the Eco-Management and Audit Scheme, EMAS, and the ISO 14,000 series). 
This paper discusses key aspects to be considered when deriving S\&KBTs for global resource use. Section 2 will start with the description of the changing background (environment) and foreground (societies). Section 3 will outline the needs of a sustainable socio-industrial metabolism, and link biophysical requirements with the SDGs. Section 4 will present essential traits on how global resources could be managed with S\&KBTs by countries. Section 5 will compile concrete proxy values of S\&KBTs for global sustainable resource use, per person for 2050, specified for biotic and abiotic resources. Finally, Section 6 will provide conclusions and a final outlook.

\section{Changing Background and Foreground}

\subsection{Tipping Points Versus Gradual Environmental Change}

Earth System Modeling is capable of describing continental scale changes of biomes and ocean systems under various scenarios of GHG emissions ([18]). This may include changes of ocean circulation strength and direction with dramatic consequences for average weather conditions in affected areas. In view of the dynamics of Earth history, where fluctuations of climate, sea level, and the shifting of biogeographical zones happened over long periods interrupted by relative short periods of disturbances, the hypothesis has been developed that there may be certain "tipping points" of environmental change beyond which the Earth System would stabilize around significantly changed equilibria of atmospheric and ocean temperature, etc. Stopping the Gulf Stream and the North Atlantic circulation would be one of those possible "tipping point" events, which may cause rather abrupt changes; dissolving permafrost soils in Siberia releasing bound methane, causing positive feedback, and enhancing climate change is another example of such tipping points ([6] and references therein).

When the consequences of land, material, and water uses are depicted, it is hard to predict the breakdown of certain life-sustaining functions at the continental level. Various observations indicate that the continuous and growing extraction and harvest of raw materials and their subsequent flows along to final disposal are associated with a gradual but continuous degradation of the environment at various locations. The level of degradation may be locally severe in mining, while it may be moderate in extensive grazing systems. The critical question is at which level of extraction, translocation, heaping up, asphalting, concreting, and deposition will the local to regional impacts sum up to a level that may have deleterious effects at the regional to continental scale also-and whether those effects would be reversible within certain time periods.

What can be observed is a growing competition for natural resources. For instance, spreading urban settlements in water-scarce regions increasingly compete with agriculture for water [19]. It may be assumed that mining and quarrying are going to reinforce the competition, as business-as-usual (BAU) projections expect a significant increase of abiotic resource extraction in the coming decades $[1,20]$. Climate change will enhance water scarcity in water-scarce regions, and even in regions that are still highly productive in agriculture. Harvest security will decline, and it will become harder to combine food and non-food biomass production, which may increase the pressure toward intensification as well as the expansion of grazed and cultivated areas. Although the intensification of agriculture may mitigate the pressure on biodiversity in other areas, the risk of soil degradation by erosion and further loss of biodiversity on the fields might increase [21].

The growing world population, insufficient governance, and lack of infrastructure together with the growing scarcity of the basic food and water supply may increase the risk of violent conflicts [22,23], although the link between resource scarcity and conflicts is often not straightforward. Meanwhile, recent evidence shows that climate change works as a "threat multiplier" [24]. Before it comes to interstate or intercommunity violence, judicial institutions are becoming involved, at least where an adequate institutional framework exists.

The Environmental Justice Atlas (https://ejatlas.org) registers legal conflicts associated with extraction, harvest, the refining of resources, infrastructures such as power plants, and the deposition of waste. These conflicts often arise from competition for clean water (e.g., agriculture and communities 
versus mining), the eviction of indigenous people by logging and agrofuel industries, pollution from refineries and power plants, and non-governmental organizations (NGOs) trying to enforce existing conservation laws.

The growing number of refugees worldwide is not only a consequence of wars and bad governance in some regions, it is to some extent also a consequence of worsening environmental conditions and threatened livelihoods, in particular the scarcity of (clean) water and food [25].

In contrast to human beings, flora and often also fauna do not have the option to flee life-threatening developments. For instance, the case of the Hambach Forest, 200 ha of oak and hornbeam vegetation remain from what had been the largest forest in the Rhineland, west of Cologne, Germany. The forest is located next to one of the largest lignite mine fields in Western Europe, and was going to be prepared for clearing in order to further expand the open pit. Nature conservation activists have protested since long ago that if the forest is cleared, the plants and many animals that live there will be killed, including red-list species [26]. Such side effects have been historically neglected by public policy, as the priority of the population in that region-and later across the whole country-had been energy security, in particular the cheap electricity, of which lignite had lately provided one-fifth to Germany. The energy company has been rigidly sticking to the mining plan issued in 1976, and did not respond to changing legislation such as the more recent Europrean Union (EU) Flora-Fauna-Habitat directive, which would have protected the area, nor did the company react to changed public opinion becoming more and more critical against the progressing change of landscape [27]. While the final survival of oak and hornbeam and Bechsteiner's bat in Europe as species would probably not depend on keeping this particular forest, the existing life in that place would be extinguished, and the creation of new habitats by reclamation activities may take decades to centuries.

Scientifically, it is difficult to foresee tipping points of resource use beyond which life-sustaining functions of ecosystems due to the sum of local land-use changes and local to regional species extinction would break down at the continental scale.

Moreover, even if there is existing knowledge to conserve species-rich areas and legislation to generally provide shelter, policy decisions may still set priorities for what is deemed societal needs against environmental concerns.

\subsection{Dynamics of Societal Choices and the Assessment of Trade-Offs}

Management targets are partially the result of a multi-faceted and multi-tier policy process [28]. Normative decisions are crucial, mostly in order to deal with trade-offs and setting priorities such as those on clearing the Hambach Forest. However, the decisions may change, in particular when either the need for change and/or the feasibility of alternative options come into perspective.

The Hambach Forest in Germany has become a signal post for environment activists involving also large demonstrations of the regional people calling for a phase out of coal, both in respect to the forest, but moreover for halting climate change [29]. The German federal government set up a multi-stakeholder commission to advise on the future of coal use. In January 2019, they came to an agreement to phase out coal for power supply in Germany until 2038 at the latest [30]. The decision was taken to enable the country to meet its obligations from the Paris Agreement, and compensations for four affected states in Germany where still lignite is mined are foreseen to facilitate the structural change. The commission also stated that it would be preferable to keep the Hambach Forest.

The conclusion of the "Coal Commission" - which in general has been adopted by the government, which prepared a law to foster structural change in the affected coal regions [31] -was supported by information about available alternatives for electricity supply mainly based on renewables, the assessment of the feasibility to secure power supply without the incineration of coal, and thus the expectation that supply security would be given also without the use of coal.

The reader will note that after the Fukushima accident, Germany had decided to phase out nuclear power by 2022 [32]. That decision was essentially driven by the motive of precaution. The remaining 
uncertainty about the risk of a similarly large nuclear accident was no longer deemed acceptable (still, the organization of final deposition of nuclear waste in Germany is unresolved).

Both management targets-phase out coal and nuclear power-give key orientation for the German government, the involved national parties, and may serve as an example for other countries as well.

Both decisions have clear effects on the use of natural resources, as hard and brown coal as well as uranium will no longer be used in Germany beyond 2038, neither from domestic extraction nor by imports. As lignite and hard coal are energy carriers with high resource and emission intensity, one may expect that this will contribute to an overall reduction of primary resource extraction and GHG emissions. Nevertheless, one has to also consider that renewable energy technologies have environmental footprints [33]. These technologies exert a high demand for special metals, and one may expect a growing environmental burden of metal mining and refining due to declining ore grades worldwide [34]. Thus, the overall effect of the phasing out of coal and nuclear on resource use and climate gas emissions will have to be monitored. One may assume that there are potentially quite many "Hambach Forests" in different regions of the world, and it is the overall extraction volume and area of open pits-for either coal or metals-that determine prior clearing; if Germany would have saved that precious place but only shifted the problems farther away, this would in the end not be a globally sustainable development.

Thus, there is a need to account for the global resource extraction that is linked to the final consumption of all goods and services within a country, reflecting the effect of technological change and substitution between products.

\section{Socio-Metabolic Needs and Development Goals}

\subsection{Universal Biophysical Requirements}

Considering the future development of resource use, not only unacceptable risks ("the bads"), should be avoided, but biogeophysical requirements ("the needs") should be considered also.

The need for supply becomes obvious with food, as human beings require a minimum input of protein, carbohydrates, and fats. In the coming decades, it may be assumed that these compounds will be further provided by biomass, cultivated by agriculture, harvested by fisheries, and produced by animal farming, including aquaculture (in the far future, those compounds could be chemically produced, e.g., from captured $\mathrm{CO}_{2}$ and $\mathrm{N}_{2}$ using renewable power). [8] described the requirements of a healthy diet, which may also spare some resources. Nevertheless, even when a minimum of food biomass per person may have been reached, a growing world population will tend to consume more food biomass.

However, there are also metabolic needs on a higher level: the socio-industrial metabolism as a whole requires materials for production and consumption as well as infrastructures (metals, construction, and industrial minerals), it needs water for heating/cooling and cleaning, it depends on energy input to drive the material and water flows, and all these flows are associated with a certain pattern of land use. The societal metabolism has been undergoing a long-term change since the era of hunter-gatherers [35], and it may be expected to undergo further significant changes by technological innovation and dynamics of human consumption [36]. Nevertheless, there are some basic features, which follow from the laws of physics and biology:

- Even when the socio-industrial metabolism uses materials and energy in a highly efficient manner and has maximized recycling for material supply, there will remain a minimum of primary input from the environment to compensate the unavoidable losses and final disposal of its excreta (i.e., waste deposition and emissions to air and water).

- The shift to renewable energies will still require the use of materials, and thus a certain amount of primary materials. 
- The higher the stock of materials in the technosphere, the higher the internal requirements for materials and energy for maintenance, repair, and refurbishment; furthermore, given certain geometry and spatial distribution, the larger the area covered by buildings and infrastructures.

As a consequence, a future sustainable metabolism, irrespective of the specific materials used, might have the following features:

(1) Material supply largely from internal recycling (and reuse, remanufacturing, etc.),

(2) Energy supply from renewables (solar, wind, etc.),

(3) The remaining inputs from and outputs to the environment staying within "safe" operational limits,

(4) The anthropogenic stock reaching a dynamic flow equilibrium (net addition to stock = zero), in order not to supersede productive and natural areas required for the survival, health, and well-being of humans and nature.

An increase of systems-wide (life-cycle-wide) material and energy efficiency within industry and society tends to contribute toward a development in line with features (1), (3), and (4). However, still, it remains open how the safe operational limits for feature (3) can be determined, and at which level of stock the flow equilibrium of feature (4) will be reached.

\subsection{Different Starting Conditions and Common Long-Term Targets}

The global population is growing, affluence is increasing, and although there is already technological change toward decoupling, global resource use is still growing and must be expected to grow further under BAU conditions [1]. Countries vary according to income, education, technology, and the status of infrastructures. The four features of a future sustainable metabolism might be reached in the various world regions at different points in time, depending on their development, including "leap frogging", and the diffusion of sustainable production and consumption patterns.

The dynamic stock equilibrium will be reached under conditions of stable population numbers and a well-developed infrastructure system. For instance, in the eastern part of Germany, it is expected to be reached around the year 2020 due to the shrinking population, while for Germany as a whole-with a stabilizing population - it may be expected before 2050 [37,38]. Indicators such as living area per person are approaching saturation in countries such as the Netherlands [39] and Norway [40], although at different levels.

Consequently, when it comes to the definition of management targets and timelines, policies will regard the different state of development of countries and their capacities for transformation. Nonetheless, progress toward a more sustainable socio-industrial metabolism could be targeted starting from any state of development, and it seems worthwhile to do so for every country in the world, and in doing so having an eye on the long-term development.

Here, some considerations are outlined for deriving possible targets for long-term development from overarching global goals.

\subsection{Linking to the SDGs}

Overarching goals can be expressed in terms of "fields of protection" such as human health and a healthy environment. Both goals are further outlined by the SDGs, which support human health (especially numbers $1,2,3,6,7)$, and those SDGs that are dedicated to sustain the climate system, life in water, and life on land (numbers 13,14,15).

Regarding the management of natural resources, material productivity targets are suggested that consider the material footprint of countries (SDG 12.2 and 8.4). These targets are aimed to foster more sustainable production and consumption systems, which would mitigate the pressures from resource extraction and final disposal, including emissions to air and water, and thus are instrumental to reach those "desired state goals". In particular, lowering material use would be another prerequisite 
for reaching the Paris targets [41]. However, targets on absolute global material resource use are still lacking.

Regarding sustainable global land use, the SDGs also exhibit some deficiencies. SDG 15 on the protection of terrestrial ecosystems and biodiversity covers the issue of land use, although still in kind of a patchy approach. A focus is on the preservation and restoration of forests; their area should not be diminished; instead, it should preferably be increased by afforestation $(15.1,15.2)$. In particular with a view on desertification and the degradation of land and soil, the SDGs include intentions to "strive to achieve a land degradation-neutral world" (15.3) and take "urgent and significant action to reduce the degradation of natural habitats, halt the loss of biodiversity" (15.5). However, the monitoring indicators only relate to the "proportion of land that is degraded" and the Red List Index. Ref. [5] suggested a safe operating space (SOS) for biodiversity on the "very preliminary" basis of species extinction not to exceed 10 times the background levels for major taxa. Ref. [6] added the aspect of functional diversity, as operationalized by BII. The aim would be to maintain BII at $90 \%$ or above (within an uncertainty range of $30 \%$ to $90 \%$ ), as "assessed geographically by biomes/large regional areas (e.g., southern Africa), major marine ecosystems (e.g., coral reefs) or by large functional groups". Current status was given with $84 \%$ only for southern Africa. Ref. [42] found that land use has already transgressed the proposed planetary boundary on $58 \%$ of the land surface, and biodiversity intactness within most biomes (especially grassland biomes), most biodiversity hotspots, and even some wilderness areas was inferred to be beyond the boundary.

S\&KBTs on biodiversity face three major challenges. (1) It is still scientifically not easy to define and measure biodiversity; many species have not even been described. (2) If "functional diversity" is introduced, this may imply that a certain loss of species could be tolerated as long as the functioning of ecosystems may be assumed; this may involve both uncertainties of modeling and ethical questions (how many species lost would be acceptable?). (3) Those SOS values are targets of the desired status of the environment. In order to approach those quality levels, management targets are required.

Management targets need to address the driving forces. A basic insight from ecosystem assessments $[43,44]$ is that the conversion of natural habitats by the expansion of agricultural and urban land is a major driver of biodiversity loss. The expansion of urban area often occurs at the expense of fertile agricultural land, and if built-up area continues to expand globally, this will further shift agriculture area into more natural habitats such as grasslands and savannahs, which are rich in biodiversity.

If biodiversity loss is to be effectively halted, this will require stopping the expansion of intensive land use at the expense of less intensively used area with higher biodiversity. In general, one could formulate the goal to strive to achieve a (net) zero conversion and (net) zero degradation land use. (Net) zero conversion would count if no land with higher biodiversity status is converted to land with lower biodiversity status. For practicality, this could be operationalized with existing categories of land use (from low to high biodiversity status): built-up land, cropland/forest plantations, intensive pasture, extensive pasture, natural grassland, savannahs/extensively managed forests, and nature conservation areas. Every country should define their targets for those types of land use, with timelines and appropriate policies. These targets (and policies) should refer both to the land use on their territory and the land used globally as a basis for their production and consumption. Such procedures could also effectively contribute to following up the Aichi targets and reach SDG 15.

Before reflecting on concrete management targets for global material and land use, it seems appropriate to consider the scales at which the management would need to be implemented.

\section{Managing Global Resource Use by Countries}

\subsection{Observing, Targeting, and Managing at Appropriate Scales}

The management of resource use is being conducted from a local to global scale [45]. Targets for globally or regionally sustainable resource use would need to be taken as orientation for policies and 
management at lower scales: national governments accounting for their country's contribution to the global issues, businesses, and communities considering global and national targets.

For some issues, the scales of observation and management are predetermined by physical and geographic conditions. Atmospheric change and global mean temperature need to be monitored globally, and management orientates toward a globally universal target. Freshwater management depends on water availability at a river basin scale. The management of ocean resources such as fish populations depend on the proper monitoring of their dynamics and distribution.

At the same time, the level of observation may differ from the level of targeting and the level of effective management. Atmospheric temperature is measured at many places around the globe. The universal target for GHG emission reduction will need management action by governments and many companies, communities, and households. Freshwater management requires the monitoring of water quality at river basin and continental scales, and management needs to coordinate actors at the river basin scale, which could be supported by national legislation, e.g., on water quality standards. The management of ocean resources-while depending on the monitoring of specific fish populations-largely requires international coordination and treaties, including control mechanisms.

When it comes to land and biodiversity, the challenge starts with observation, as biodiversity has been recognized from genetic (species) to biome diversity. Traditionally, nature conservation policies focus on species richness. Certainly, the Convention on Biological Diversity (CBD) has the goal to halt the loss of animal and plant species on this planet. Species diversity is regarded as an important element for the functioning and resilience capacity of natural ecosystems [44]. There are also ethical underpinnings for such a goal, as the co-existence of human beings with other species can be regarded as a value per se.

Linking the risk of biodiversity loss to activities in production and consumption is possible on a product basis by life-cycle assessment approaches. For instance, [46] showed that a liter of bioethanol from sugar beet in France is associated with a lower risk of species extinction than a liter of bioethanol from sugar cane in Brazil, mainly because the natural vegetation in Brazil would harbor higher species diversity than the natural vegetation in France. However, the analysis neglects what may happen if Europeans would demand more ethanol from France instead of Brazil. It is probable that food and feed production in France would shift, possibly to South America, e.g., to import soy for feeding cattle, as domestic fodder production in France (e.g., maize) would have less area available due to expanding sugar beets for ethanol.

Substitution dynamics may be better reflected by multi-regional input-output models, which capture international trade relations $[39,42]$. That approach allows determining the environmental footprints of the whole production and consumption of countries, in terms of primary materials, land, and water use [45]. These basic pressures can then be related to final impacts such as the risk of biodiversity losses, although with much higher uncertainty, and usually with results that may be interpreted only in relative terms. It is still unresolved research whether modeling will also allow a comparison with an absolute target value of zero species loss. What seems feasible is to determine scenarios with no net land conversion, or at least significantly reduced land conversion compared to business-as-usual [1].

This information could be used to derive management targets. For instance, for a country such as Switzerland, it turned out that the import of cacao is the highest threat to global species diversity exerted by Swiss production and consumption [46]. If the government has an interest in lowering this pressure, it may be important to talk to their food industry to possibly source from less species-rich regions (which for cacao might be prone to problem shifting) and use less cacao for their products, eventually considering an adjustment of the taxes, and combining this with information campaigns to consume less sweets. However, in order to induce the government to become active and act globally responsible, they might want to know whether their overall production and consumption leads to pressures on global biodiversity that is above or below global average, and whether a global target has been exceeded. 
The question is also whether such targets would allow countries to reach them by patching up ("wedges"), i.e., implementing portions by complementary measures, which also leave flexibility and the option of varying preferences. For instance, Germany's footprint of agricultural imports in terms of land use is determined by soy cake and cacao. If consumers want to reduce this footprint, they can either eat less meat and dairy products, less sweets, or less of both, thus consuming a more healthy diet and contributing to reduced pressure on global cropland expansion, which is a key driver of biodiversity loss. The government could adapt the incentive and information framework to motivate consumers to do so.

A "macro management" of resource use by governments could be directed toward an adjustment of production and consumption patterns as well as infrastructure planning, operation, maintenance, and substitution (Figure 1). It could set policies and incentives for the actors to use materials, energy, and products more efficiently and prefer those products and services with the smallest footprints. For that purpose, governments could orientate their measures based on headline indicators such as resource and climate footprints. When the national values exceed the global S\&KBTs, the most relevant production sectors and consumption areas should be addressed with effective policy measures (ranging from soft instruments such as improved information to hard instrument such as taxes and levies; examples are given in [1,2]).

This would complement the "micro management" at the level of communities, companies, and farms (e.g., involving instruments to determine land potential [47]), and the existing nature conservation policies. The latter is based on assigning a certain protection status to delineated areas. While that approach was successful in helping mitigate biodiversity losses in some regions, it is often insufficient to control the economic pressure of a growing demand to transgress the protection boundaries or undermine the protection status. In order to stay effective, conventional nature protection needs to be complemented by macro management policies to control the demand for natural resources.

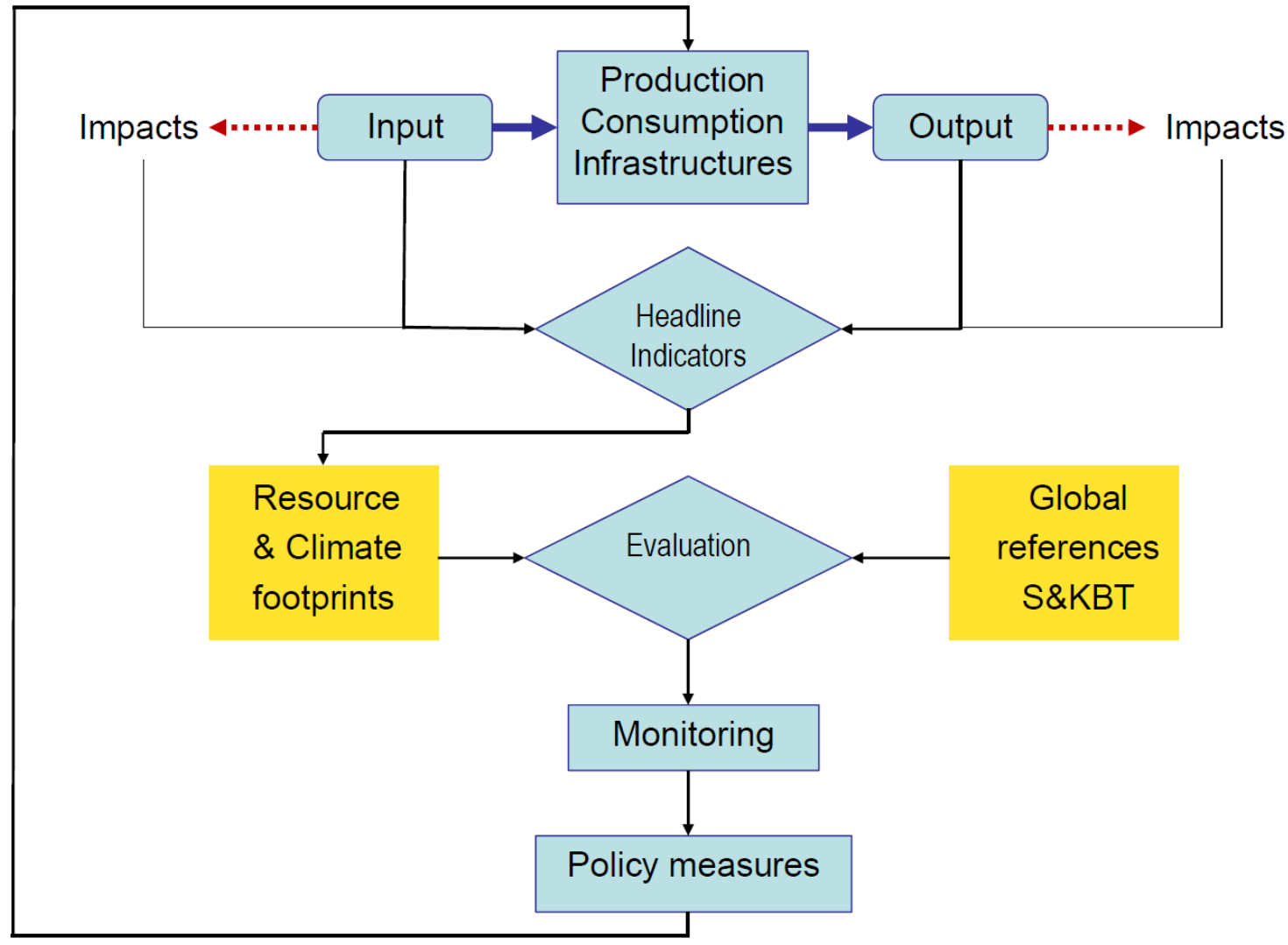

Figure 1. Scheme of macro management of global resource use by national governments. 


\subsection{Actionable and Directionally Safe Management Targets}

Management needs to be efficient and effective. For governments, the challenge is to establish the adequate indicators and methods to derive targets that are actionable (being appropriate to take action upon) and at the same time sufficiently directionally safe.

Directionally safe means that the indicators and targets can be interpreted with sufficient reliability so that derived decisions and actions for the most part have the expected (desired) effect. For instance, the total extraction of primary materials from nature may be assumed to indicate the magnitude of related environmental impacts, so that a higher mass flow indicates higher environmental impacts, and lower flows reduced impacts. While this assumption seems generally plausible at the country and local scale, there may be cases where a local increase of extraction may be associated with an overall lower environment burden at the country scale if larger reductions of extractions would be realized at other locations. Decisions aiming to reduce the overall extraction at the country level would still be directionally safe when aiming to reduce environmental impacts.

Regarding biodiversity, the orientation on broad land-use categories would have the advantage of being (1) relevant with regard to biodiversity, (2) already reported by national statistics, and (3) attributable to actor groups.

When net zero land conversion is adopted as an overarching management goal, the question will be on the adequate scale and required spatial resolution to decide on net changes. As urban sprawl continues around the gravitation centers of human population, while rural areas become less populated and infrastructures may be shrinking, there will be processes that compensate or at least partially restore area that has formerly become built up. Approaching the flow equilibrium of the anthropogenic stock will lead to a balance of erecting new buildings and deconstructing old ones, mostly at the same places, but also at different locations, but with the overall balance of approaching a maximum level of built-up area at the global, continental, and national levels.

Settlements comprise not only completely sealed surfaces, but also contain gardens and often harbor significant fauna. In contrast, cropland as cultivated in high production regimes often resembles a "green desert" with a minimum of species diversity. Globally, the expansion of cropland into grassland and savannah seems to exert relatively higher pressure on species diversity than the expansion of settlements, as both types of land use may be expected to expand by about the same order of magnitude (about $3 \mathrm{Mkm}^{2}$ ) from 2010 to 2060 [10,44], and settlements tend to convert species-poor cropland, while cropland tends to expand into species-rich(er) grassland and savannah [43]. The same applies for the expansion of total agriculture land. Both trends-the expansion of urban area and the extension of agricultural area-occur at the expense of forests, mainly in the tropical belt.

A target corridor for forest area has been proposed by [6] at the global and biome level, based on forested area as a percentage of original forest cover, and of potential forest, respectively. Globally, $54 \%$ to $75 \%$ are defined as a "zone of uncertainty", so that the SOS-the target corridor-would range above $75 \%$. This is compared with status quo of $62 \%$, i.e., a value within the uncertainty zone. For tropical and boreal biomes, the authors suggested $85 \%(60 \%$ to $85 \%)$, and for temperate biomes, the authors suggested $50 \%$ (30\% to $50 \%)$ as SOS (uncertainty zone) values.

These targets for the desired status of the environment may inform conventional conservation policies. However, they are not directly useable for effective macro management, as the major pressures of deforestation come from activities outside the forests such as agriculture, and their activities are driven by production and consumption. Thus, macro management targets are badly needed that capture the key driver for global biodiversity loss and provide leverage points for resource management by governments.

For orientation toward this end, [48] proposed to halt the BAU expansion of global cropland until 2020, which would then cover 1.64 billion hectares. 


\subsection{Attribution of Global Targets to Countries}

It seems important to distinguish between the production and consumption perspectives. Countries differ in size and natural endowments, both regarding mineral resources and land harboring biotic resources. It would be neither fair nor environmentally sensible to restrict the mining or agricultural production of a country to the number of their inhabitants. At the same time, global population is converging more and more with regard to the per-person final consumption of goods and services. This trend, together with the principle of equity, suggests attributing the equal right to use natural resources to the final consumption of goods and services on a per-person basis.

Following this consideration, the proxy target of 1.64 Gha cropland was related to a global population of 8.2 billion expected in 2030, providing a value of $0.20 \mathrm{ha} /$ person cropland used for the final consumption of agricultural goods [48]. Such an orientation value can be used as a reference and benchmark of national performance. For instance, [49] found that the EU's final consumption of agricultural goods required $0.29 \mathrm{ha} /$ person in 2011, which exceeded not only the available cropland on its own territory ( $0.24 \mathrm{ha} /$ person) (indicating that the EU is a net cropland importer), but also exceeded the global average of cropland used ( $0.22 \mathrm{ha} /$ person). This observation and earlier findings [14] were taken into account when revising the EU's biofuel policy by redefining their mandatory quota.

Attributing natural resource use to the final consumption of goods is also in line with the causative principle (formerly the polluter-pays principle) in terms of the responsibility of public and private consumers for the environmental burden associated with the footprints of their consumption. It is also in line with the responsibility of producers who need to account for the life-cycle-wide performance of their products and services.

The attribution of natural resources to the final consumers does not impair ownership rights, either on land, mineral deposits, manufactured products, or purchased products. Also, national sovereignty would not be compromised by macro management that targets resource use related to final consumption.

\section{Toward Management Targets for Global Resource Use}

Human-induced material flows from extraction to final disposal are kind of a conveyor belt that is associated with bundles of various environmental impacts. The magnitude of those impacts cannot be changed toward safe, i.e., acceptable low risk, level, without adjusting the flows accordingly.

Managing material flows in a sustainable manner will require complementary action at different scales [45]. Also, for the management of global resource use, it is suggested to distinguish between micro management and macro management. The former is going to be practiced at the local level (farmers, foresters, fisheries, mining companies) and may involve also product certification that aims to support sustainable cultivation or mining schemes, respectively. The latter is generally conducted by national governments, setting their incentive framework in a way that the fair and safe share of the nation's use of global resources would not be exceeded.

\subsection{Biotic Resource Use}

In order to approach a balanced and sustainable bioeconomy, it seems important that food production should be first priority, that each hectare is cultivated in a sustainable manner, and that the number of cultivated hectares necessary to supply final demand is kept within a safe limit (Table 1).

Micro management at the farm and forest level depends on criteria of good practice, which need to be provided for and monitored at the local level. Various certification schemes exist, and the proportion of certified cultivation schemes could be a target indicator. For fisheries, in particular marine harvest needs to be adjusted to sustainable levels to be determined for every commercial species and fishing grounds.

For macro management, it has been suggested to limit the cropland required for the final consumption of agricultural goods to 0.20 ha/person in 2030, corresponding to 0.16 ha/person in 2050 . 
The rationale for the per-hectare basis was to contribute to halting the loss of global biodiversity by land-use change. At the same time, one has to consider that the productivity of agricultural land differs greatly from region to region, which is dependent on soil, weather, climate, and technology. Nevertheless, people are consuming an increasing variety of crop-based goods from various regions and cultivation schemes, so that this consumption-oriented target may be acceptable, in particular when applied for whole economies rather than at the level of the individual, and assuming an equal right to use goods produced on the same extent of cropland.

In order to control forest degradation by overuse, no more timber should be harvested than what is regrowing. Based on available data on the net annual increment of world and European forests up to 2014, [50], assuming the current structure of existing forests to persist, suggested first orientation values for a safe limit of timber-based consumption. As Europe has highly productive forests and a larger endowment with forests compared to other regions, and has cultural roots to use timber products, the orientation for that continent could be rather the domestic supply capacity $\left(1.2-1.4 \mathrm{~m}^{3} /\right.$ person in 2050) than a global average $\left(0.3-0.5 \mathrm{~m}^{3} /\right.$ person in 2050).

Table 1. Management approaches and possible targets for the global sustainable use of biotic resources. EU: European Union. t.b.d.: to be determined.

\begin{tabular}{|c|c|c|c|}
\hline \multirow{2}{*}{$\begin{array}{c}\text { Biotic } \\
\text { Resources }\end{array}$} & \multirow{2}{*}{$\begin{array}{l}\text { Micro Management } \\
\text { Addressing Primary Sector }\end{array}$} & \multicolumn{2}{|c|}{$\begin{array}{l}\text { Macro Management } \\
\text { Addressing Manufacturing and Final Consumption }\end{array}$} \\
\hline & & Resource-Specific Target & Compound Target \\
\hline Agriculture & \multirow{2}{*}{$\begin{array}{l}\text { Shift toward sustainable } \\
\text { cultivation schemes (certified } \\
\text { proportion to increase) }\end{array}$} & $\begin{array}{l}0.20 \text { ha/person cropland in } 2030 \\
0.16 \text { ha/person in } 2050\end{array}$ & \multirow{3}{*}{$\begin{array}{l}2 \mathrm{t} / \text { person primary } \\
\text { biomass in } 2050\end{array}$} \\
\hline Forestry & & $\begin{array}{c}0.4 \mathrm{~m}^{3} / \text { person primary timber (world) in } 2050 \\
1.3 \mathrm{~m}^{3} / \text { person primary timber (EU) in } 2050\end{array}$ & \\
\hline Fisheries & $\begin{array}{l}\text { Respect safe maximum quota } \\
\text { for each commercial species }\end{array}$ & t. b. d. & \\
\hline
\end{tabular}

Macro management of the consumption of fishery products may be performed in conjunction with the promotion of more healthy and sustainable diets.

When the overall harvest/extraction of biotic material resources shall be monitored to provide an orientation of possible risk levels, a compound value of $2 \mathrm{t} /$ person of primary biomass could be taken as a proxy [20]. This value results from keeping the global $21 \mathrm{Gt}$ in 2000 rather constant, and attributing it to a world population of 9.55 billion in 2050, assuming that growing food demand could be compensated by reduced losses of food biomass. The order of magnitude applies both to total primary extraction and used harvest, comprising $85 \%$ to $90 \%$ agricultural biomass and $10 \%$ to $15 \%$ timber, with marine and wild fish catch vanishing in the rounded number. That data can be directly related to the economy-wide Material Flow Accounts database of the International Resource Panel (IRP) for benchmarking.

\subsection{Abiotic Resources}

Micro management for abiotic resources is related to minimizing the environmental (and detrimental social) impacts of mining and quarrying within the local context of extraction, beneficiation, and refining. Principles of good mining practice and lists of criteria to consider are available (e.g., 10 principles of the International Council on Mining \& Metals, ICMM: https: //www.icmm.com/en-gb/environment/managing-metals-sustainably), and the IRP is going to provide a report on sustainable licensing to operate. Product certification schemes have been established that focus on their origin and the performance of primary production (e.g., to exclude "blood diamonds").

For macro management, the long-term perspective of the socio-industrial metabolism (Section 3.1) and the aggregated effects of abiotic resource extraction and their proximate and ultimate final disposal need to be considered. Even when micro management results in minimizing the local to regional 
impacts, mining and quarrying will still severely alter and degrade the excavated and surrounding area with larger impacts on hydrology, vegetation, and landscape, depending on the overall amount extracted. For Earth Systems functioning, looking at it with coarse grain, a certain number of these "scars" may be tolerable; single abandoned limestone quarries may even harbor some red-list species. However, continued at the high level or even growing volume flow, the extraction and disposal of mineral resources-which due to the nature of non-renewables proceed to devastate new areas-those scars will become deeper and larger, and they will become denser. With the number of extraction, refining, and disposal sites, the number of conflicts with the local population, agriculture, forestry, and nature conservation will increase.

Moreover, similar to environmental management at the company level, macro management also has to consider both orderly processes and accidents. With a certain frequency, depending on the stringency of governance in the world regions, mining operations are the cause of environmental disasters (e.g., hundreds of people killed or large rivers being severely polluted by breaking tailing dams).

The availability of mineral resources in the Earth crust seems to be rather sufficient. What is really scarce is conflict-free access to the deposits and low environmental risks of extraction, refining, and disposal.

As a consequence, also in view of the principle of precaution, the extraction of minerals from natural deposits should be reduced to the unavoidable minimum (Table 2).

For fossil fuels, the issue of climate change adds another pressing demand: the mitigation of climate change. It seems clear that the world has to phase out the combustion of fossil fuels. The energy can be provided by renewable sources. When carbon is needed, in particular to supply the chemical industry, the recycling of materials as well as using $\mathrm{CO}_{2}$ as raw material is possible, and will be an essential component of the future socio-industrial metabolism [51], although technologies differ with regard to their footprints [52].

Table 2. Management approaches and possible targets for the global sustainable use of abiotic resources.

\begin{tabular}{|c|c|c|c|}
\hline \multirow[t]{2}{*}{ Abiotic Resources } & \multirow{2}{*}{$\begin{array}{l}\text { Micro Management } \\
\text { Addressing Primary } \\
\text { Sector }\end{array}$} & \multicolumn{2}{|c|}{$\begin{array}{l}\text { Macro Management } \\
\text { Addressing Manufacturing and Final Consumption }\end{array}$} \\
\hline & & Resource-Specific Target & Compound Target \\
\hline Fossil fuels & \multirow{4}{*}{$\begin{array}{l}\text { Increase the share of } \\
\text { certified responsible } \\
\text { mining and quarrying }\end{array}$} & $\begin{array}{l}\text { Phase out incineration } \\
\text { Shift to renewable energy } \\
\text { Shift to carbon recycling }\end{array}$ & \multirow{4}{*}{$\begin{array}{l}6-12 \mathrm{t} / \text { person primary } \\
\text { extraction in } 2050\end{array}$} \\
\hline Metal minerals & & Minimize need of primary & \\
\hline Construction minerals & & extraction & \\
\hline Industrial minerals & & Shift to recycling & \\
\hline
\end{tabular}

For metal products, reuse, remanufacturing, and in particular recycling have already reached a significant level, while unused potentials still exist [20,47].

For construction minerals, cascading the use of demolishing waste is widely practiced; urban mining becomes more and more state-of-the-art in order to proceed toward high-level recycling, including recycling aggregates from concrete and recycling even gypsum from plasterboard. Supplying construction activities from deconstruction will become easier, consequently, the closer societies will come to the saturation of their construction stock.

Industrial minerals represent a relative minor portion of total mineral extraction. For some minerals, such as kaolin for ceramics, it may be difficult to find mineral substitutes. Carbon fibers and polymers based on recycled carbon may provide some options, but feasibility will have to be researched.

In 2010, all the anthropogenic mineral extractions were estimated to reach 135 to $150 \mathrm{Gt}$, thus exceeding the natural mass flows modeling the Earth's crust such as by volcanism by four or five times (if only the extrusive magma flows are accounted for, the difference would be 68 to 75 times [20]). Against that background and reviewing earlier target proposals for sustainable mineral 
extraction, [20] suggested a target corridor of 6 to $12 \mathrm{t} /$ person for 2050. The range was determined in a constructive approach: return to half to a full level of extraction in 2000. These values can be interpreted as aggregate proxy values of orientation, reflecting that for landscape changes and orders of magnitude of local conflicts, it may be less determinant whether ores or construction minerals, fossil fuels, or industrial minerals are extracted and refined rather than the magnitude of those operations that relate to the overall extraction and translocation of natural materials on the surface of the Earth's crust.

In the absence of detailed specific cause-effect relationships and their overall impacts, considering mainly the general aspect that the mass turnover of primary materials is the basic determinant of related environmental pressure and regarding the risk of societal conflicts with mining, quarrying, and final deposition, those values may be regarded as precautionary values for orientation. If they are trespassed by the overall production and consumption of a country, this may be regarded as an early warning that some adaptation of the policy framework would be needed in order to adjust those patterns toward a more sustainable performance.

If such macro targets are to be implemented at the micro level, the environmental management of companies could do so by controlling the material footprint of their products [53]. For that purpose, indicators can be used that are already reported. For example, at EU level, there are the raw material input (RMI) and raw material consumption (RMC) [54]. Both comprise the biotic and abiotic used extraction of raw materials (without the unused part of total extraction). The former is the material flow basis for production and accounts for domestic extraction plus imports including their raw material equivalents, while the latter reflects the material flows for final domestic consumption and subtracts exports and their raw material equivalents from the RMI. Based on the possible compound targets for biotic and abiotic material resource extraction (used and unused) shown in Tables 1 and 2, [20] derived a range of 3 to $6 \mathrm{t}$ RMC per person in 2050, comprising $2 \mathrm{t} /$ person biotic harvest. For purposes of easy communication, a concrete value of $5 \mathrm{t}$ RMC per person in 2050 was suggested as a possible target for global RMC. Considering that the EU industry produces both for domestic and foreign consumption (via exports), assuming that the relation of RMI/RMC remains unchanged (19.6 $\mathrm{t}$ per person/14.2 $\mathrm{t}$ per person in 2016), and that the EU's population will remain rather constant and 150 million persons will be further employed by business, a possible target for the material footprint of $24 \mathrm{t}$ RMI per employee $_{\text {business }}$ could be derived for 2050. Compared to the $67 \mathrm{t}$ RMI per employee business $_{\text {in }} 2016$, this would require a reduction of nearly two-thirds $(64 \%)$. The consideration of the material footprint of the purchases of companies is already foreseen in the 2017 update of the Eco-Management and Audit Scheme (EMAS) [55].

Phosphate is a relevant industrial mineral that is also indispensable as a fertilizer in agriculture. Due to its dispersive way of application, there are unavoidable losses, so that a certain amount of phosphate mining will remain indispensable in the foreseeable future; the recycling of phosphorous from waste water is going to be conducted to a growing extent, but will only be capable of recycling smaller flows compared to those being managed in agriculture. Phosphorus mining and refining is challenged as the remaining larger deposits have relatively high amounts of contaminants such as cadmium, and may require a significant amount of water for refining. The bundle of those impacts may be reduced when keeping the extraction to the necessary minimum by well-described measures including measures to reduce food waste [56] (see also http://phosphorusfutures.net/phosphorus-sustainability/).

Consumption-oriented measures and targets aiming to stabilize global biomass harvest, i.e., the biotic part of resource use, may have not only a profound effect to mitigate the necessity of phosphorous mining. Such reduction will also help to mitigate the eutrophication of aquatic ecosystems, which is largely caused by phosphor compounds leached from fertilized fields.

Another major cause of global eutrophication is the input of nitrogen to natural ecosystems. Crop production is the single largest cause of human alteration of the nitrogen cycle. Mineral fertilizer represents nearly half of the nitrogen input, while nearly two-fifth of the nitrogen input is being lost in natural ecosystems [57]. While farming can manage to supply nitrogen by cropping systems 
integrating nitrogen-fixing plants, conventional agriculture is still bound to chemical nitrogen fertilizer. The ammonia part is coming from the Haber-Bosch process, which transforms inert molecular nitrogen from the atmosphere to chemically-active nitrogen compounds. This activation process had not only been the basis of the green revolution, improving food supply for many people, it also remains the starting point of the nitrogen-based eutrophication of many terrestrial and aquatic ecosystems worldwide. The limit suggested by [6] based on [58] is $62 \mathrm{Tg} \mathrm{N} / \mathrm{a}$ from industrial and microbial fixation. From a macro management point of view, in the end, such a target would require a limitation of industrial production of activated nitrogen worldwide. The adequate level will have to be determined by dedicated modeling, including scenarios considering technical development and varying agricultural practice.

For freshwater use, targets at the global level would seem inadequate in view of the varying water availability of river basins around the world. While a future convention on the sustainable use of natural resources may formulate general goals such as "not to use more water than what is sustainably available for humans and the natural environment", the management will basically have to be performed on the river basin scale. There, it would rather be a kind of a meso management, because the various actors of the region have to be addressed and included in integrated water management. Nevertheless, macro management by national governments could help monitor water use and the effectiveness of water management in the river basins, issuing targets of water quality and adjusting the incentive framework if necessary, e.g., to promote water-use efficiency or limit the number of cattle per farm hectare to reduce eutrophication. Governments could also monitor the water footprints of their country based on the AWARE approach in order to reveal which parts of their production and consumption are coming from regions with high water scarcity [59], and if so, provide incentives for change.

\section{Outlook}

\subsection{Conclusions so Far}

When considering S\&KBTs, it seems advisable to distinguish between targets of desired environmental state and the management targets aiming to reach it. Management targets need to be closer to the driving forces in production and consumption.

Besides micro management at the level of mines, farms, and forests, also including the certification schemes of products, a macro management for sustainable resource use is needed at the level of national governments.

Scientific analysis cannot answer the question of which state of the environment-or losses of its quality-will be acceptable to societies. To answer this question, wider knowledge, including normative and ethical aspects, have to be considered.

The use of natural resources is not only associated with environmental impacts, but also with a growing number of social conflicts. Thus, limiting natural resource use to sustainable levels becomes a matter of conflict avoidance.

Science-based and knowledge-based management targets of resource use should adopt a long-term perspective (2050-2100) and consider the structure, dynamics, and spatial pattern of the socio-industrial metabolism worldwide and in every region.

Essential traits of a future sustainable socio-industrial metabolism together with the existing policy goals such as the SDGs can be used to derive some first management targets for global sustainable resource management at the macro level.

The possible targets presented in this article should be further discussed and tested. If there is any substantial evidence that the proxy targets would be misleading, they should be adapted or skipped. Based on current knowledge, the suggested targets may be deemed directionally safe for the coming decades. 


\subsection{Target Setting and Societal Learning}

Resource policies, similar to governance in general, must proceed on the basis of available knowledge. It cannot wait until every detail on the environmental and social impacts of resource use have been scientifically proven. Such a conservative approach would also tend to be reactive and could hardly be effective in a precautionary manner. As long as the basic assumptions seem valid and the indicators and targets can be deemed directionally safe, governments and industries can proceed and define their resource management targets.

Nevertheless, societies and businesses will learn while pursuing their targets. Additional scientific findings and improved knowledge may lead to an adjustment, supplement, or even redefinition of targets and timelines (Figure 2). Target setting may be regarded as a necessary, though not sufficient element in the transformation process.

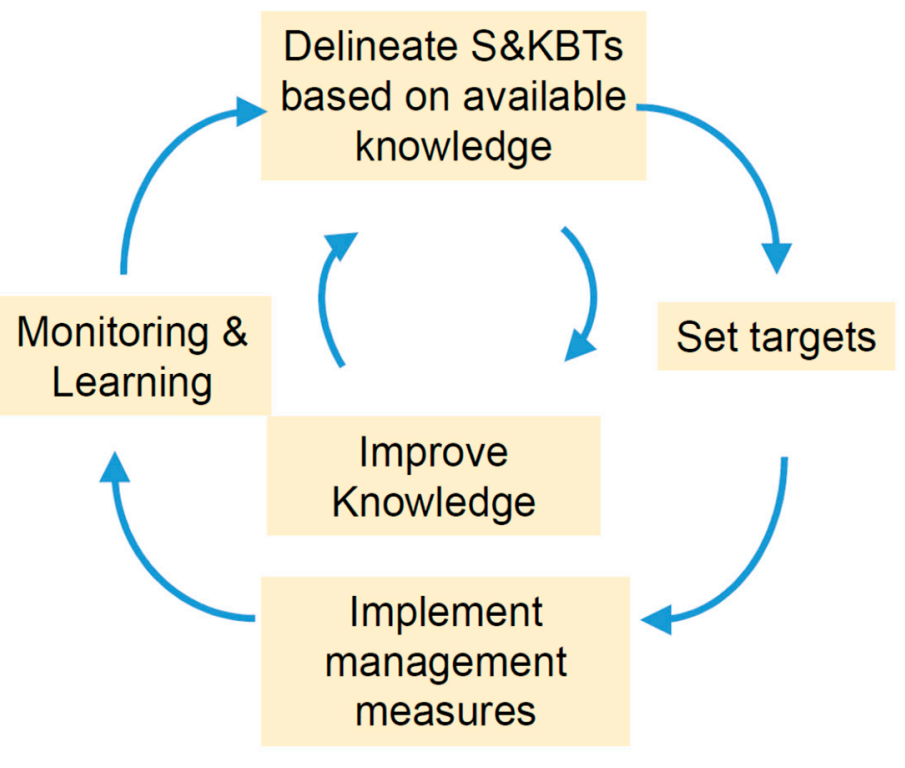

Figure 2. Target setting and testing as part of a societal learning process.

\subsection{Actions Needed}

Further progress toward the implementation of S\&KBT for the sustainable use of natural resources requires the engagement of various actors.

\subsubsection{Science and Research}

Scientific modeling can help to further elucidate the linkages of human activities and the environmental impacts. Anthropogenic material flows basically determine those linkages. Scenario modeling, such as that conducted for the GRO2019 report [1], should be used to explore under which conditions and with which impacts the proxy targets presented here could be reached. For instance, the contribution of national resource efficiency (savings) and circular economy (recycling) on global resource use and spatially specified impacts could be modeled.

\subsubsection{Discussion and Agreement between Involved Actors}

The setting of policy targets will have to involve all the parties contributing to the policy process. Better informed by scientific input and wider knowledge, decisions will still have to be taken on the basis of some uncertainty, so that a discussion of acceptable levels of risk and advisable thresholds of global resource use seems necessary.

Governments, business, and NGOs will need to be involved. Science-driven networks such as the science-based targets network [60], or sustainability reporting initiatives such as r3.0 [61] may 
facilitate the further processes. As the issue of global resource use involves all countries, the United Nations may be expected to play a key role. While scientific panels such as the IRP can provide advice, discussion on policy targets may enter agendas, for instance, of the High Level Political Forum on Sustainable Development [62] and the World Economic Forum [63]. Similar to many other institutions, NGOs will have to become engaged and become aware that climate and resource issues need to be treated together.

\subsubsection{Testing S\&KBTs}

Some countries such as Japan and Germany have established resource efficiency targets and may also consider supplementing targets on absolute resource use for their product consumption. Their experiences should be further monitored (such as by [64]) and evaluated.

Pilot companies may decide to integrate resource use targets into their monitoring and controlling. The update of the Eco-Management and Audit Scheme (EMAS [65]) directive of 2017 requires certified companies to consider the resource requirements of their purchases, which would be a good occasion to include appropriate targets as well.

Funding: This research received no external funding.

Conflicts of Interest: The author declares no conflict of interest.

\section{References}

1. Oberle, B.; Bringezu, S.; Hatfield-Dodds, S.; Hellweg, S.; Schandl, H.; Clement, J.; Cabernard, L.; Che, N.; Chen, D.; Droz-Georget, H.; et al. IRP (2019) Global Resources Outlook 2019: Natural Resources for the Future We Want. A Report of the International Resource Panel; United Nations Environment Programme: Nairobi, Kenya. Available online: https://wedocs.unep.org/bitstream/handle/20.500.11822/27517/GRO_2019. pdf? sequence $=3 \&$ isAllowed $=y$ (accessed on 14 July 2019).

2. $\quad$ Ekins, P.; Hughes, N.; Bringezu, S.; Arden Clark, C.; Fischer-Kowalski, M.; Graedel, T.; Hajer, M.; Hashimoto, S.; Hatfield-Dodds, S.; Havlik, P.; et al. UNEP (2017) Resource Efficiency: Potential and Economic Implications. A Report of the International Resource Panel. Available online: http://wedocs.unep.org/bitstream/handle/20.500. 11822/21230/resource_efficiency_potential_economic_implications.pdf?sequence=1\&isAllowed=y (accessed on 14 July 2019).

3. Bringezu, S.; Ramaswami, A.; Schandl, H.; O’Brien, M.; Pelton, R.; Acquatella, J.; Ayuk, E.; Chiu, A.; Flanegin, R.; Fry, J.; et al. IRP (2017) Assessing Global Resource Use: A Systems Approach to Resource Efficiency and Pollution Reduction. A Report of the International Resource Panel. United Nations Environment Programme: Nairobi, Kenya. Available online: http://wedocs.unep.org/bitstream/handle/20.500.11822/22583/ Full\%20Report\%20-\%20Assessing\%20Global\%20Resource\%20Use.pdf?sequence=1\&isAllowed=y (accessed on 14 July 2019).

4. Raworth, K. A safe and just space for humanity: Can we live within the doughnut. Oxfam Policy Pract. Clim. Change Resil. 2012, 8, 1-26.

5. Rockström, J.; Steffen, W.; Noone, K.; Persson, Å.; Chapin, F.S., III; Lambin, E.F.; Lenton, T.M.; Scheffer, M.; Folke, C.; Schellnhuber, H.J.; et al. A safe operating space for humanity. Nature 2009, 461, 472. [CrossRef] [PubMed]

6. Steffen, W.; Richardson, K.; Rockstrom, J.; Cornell, S.E.; Fetzer, I.; Bennett, E.M.; Biggs, R.; Carpenter, S.R.; de Vries, W.; de Wit, C.A.; et al. Planetary boundaries: Guiding human development on a changing planet. Science 2015, 347. [CrossRef] [PubMed]

7. Max-Neef, M.A. Human Scale Development: Conception, Application and Further Reflections; The Apex Press: New York, NY, USA, 1992.

8. Willett, W.; Rockström, J.; Loken, B.; Springmann, M.; Lang, T.; Vermeulen, S.; Garnett, T.; Tilman, D.; DeClerck, F; Wood, A.; et al. Food in the Anthropocene: The EAT-Lancet Commission on healthy diets from sustainable food systems. Lancet 2019, 393, 447-492. [CrossRef]

9. Rao, N.D.; Min, J. Decent Living Standards: Material Prerequisites for Human Wellbeing. Soc. Indic. Res. 2018, 138, 225-244. [CrossRef] 
10. Hertwich, E.; van der Voet, E.; Suh, S.; Tukker, A.H.M.; Kazmierczyk, P.; Lenzen, M.; Mc-Neely, J.; Moriguchi, Y. UNEP (2010) Assessing the Environmental Impacts of Consumption and Production: Priority Products and Materials. A report of the Working Group on Environmental Impacts of Products and Materials to the International Panel for Sustainable Resource Management. Available online: http:/www.unep.fr/shared/ publications/pdf/DTIx1262xPA-PriorityProductsAndMaterials_Report.pdf (accessed on 14 July 2019).

11. Vita, G.; Hertwich, E.G.; Stadler, K.; Wood, R. Connecting global emissions to fundamental human needs and their satisfaction. Environ. Res. Lett. 2019, 14, 014002. [CrossRef]

12. Masson-Delmotte, V.; Zhai, P.; Pörtner, H.-O.; Roberts, D.; Skea, J.; Shukla, P.R.; Pirani, A.; Moufouma-Okia, W.; Péan, C.; Pidcock, R.; et al. (Eds.) IPCC: Summary for Policymakers. In Global Warming of $1.5^{\circ} \mathrm{C}$. An IPCC Special REPORT on the Impacts of Global Warming of $1.5^{\circ} \mathrm{C}$ Above Pre-Industrial Levels and Related Global Greenhouse Gas Emission Pathways, in the Context of Strengthening the Global; World Meteorological Organization: Geneva, Switzerland, 2018.

13. European Environmental Agency (EEA). Environmental Indicators: Typology and Overview; Smeets, E., Weterings, R., Eds.; EEA Technical Report No 25; European Environmental Agency (EEA): Copenhagen, Denmark, 1999; p. 19.

14. Bringezu, S.; O’Brien, M.; Schütz, H. Beyond biofuels: Assessing global land use for domestic consumption of biomass. Land Use Policy 2012, 29, 224-232. [CrossRef]

15. Bührs, T. Environmental Space as a Basis for Legitimating Global Governance of Environmental Limits. Glob. Environ. Polit. 2009, 9, 111-135. [CrossRef]

16. Häyhä, T.; Lucas, P.L.; van Vuuren, D.P.; Cornell, S.E.; Hoff, H. From Planetary Boundaries to national fair shares of the global safe operating space-How can the scales be bridged? Glob. Environ. Change 2016, 40, 60-72. [CrossRef]

17. O’Neill, D.W.; Fanning, A.L.; Lamb, W.F.; Steinberger, J.K. A good life for all within planetary boundaries. Nat. Sustain. 2018, 1, 88-95. [CrossRef]

18. Myhre, G.; Shindell, D.; Bréon, F.-M.; Collins, W.; Fuglestvedt, J.; Huang, J.; Koch, D.; Lamarque, J.-F.; Lee, D.; Mendoza, B.; et al. Anthropogenic and Natural Radiative Forcing; UN Environment: Nairobi, Kenya, 2013; ISBN 978-1-107-05799-1.

19. Flörke, M.; Schneider, C.; McDonald, R.I. Water competition between cities and agriculture driven by climate change and urban growth. Nat. Sustain. 2018, 1, 51-58. [CrossRef]

20. Bringezu, S. Possible Target Corridor for Sustainable Use of Global Material Resources. Resources 2015, 4, 25-54. [CrossRef]

21. UN Environment (Ed.) Global Environment Outlook 6; UN Environment: Nairobi, Kenya, 2019.

22. Evans, A. Resource Scarcity, Climate Change and the Risk of Violent Conflict; World Development Report 2011, Background Paper; World Bank: Washington, DC, USA, 2011.

23. Blondel, A. Climate Change Fuelling Resource-Based Conflicts in the Asia-Pacific; Asia-Pacific Human Development Report Background Papers Series NY2012/12; United Nations Development Programme: New York, NY, USA, 2012.

24. Koubi, V.; Spilker, G. Natural Resources, Climate Change, and Conflict. In Oxford Research Encyclopedia of Politics; Oxford University Press: Oxford, UK, 2017.

25. McAuliffe, M.; Martin, R. World Migration Report 2018; World Migration Organization: Geneva, Switzerland, 2017.

26. BUND. Background Briefing on Hambach Forest. Available online: http://www.foeeurope.org/sites/default/files/ extractive_industries/2018/2017_11_bund-background_hambacher_forst_en1.pdf (accessed on 15 July 2019).

27. Imboden, C.; Moczek, N. Risks and Opportunities in the Biodiversity Management and Related Stakeholder Involvement of the RWE Hambach Lignite Mine; IUCN: Gland, Switzerland, 2015.

28. Hill, M.; Varone, F. The Public Policy Process, 7th ed.; Routledge: Abingdon, UK, 2017.

29. Rousseau, D.; Schreiber, Y. “Generation climate” to Occupy Huge German Coal Mine-The Local. 2019. Available online: https://www.thelocal.de/20190619/generation-climate-to-occupy-huge-german-coal-mine (accessed on 16 July 2019).

30. Bundesministerium für Wirtschaft und Energie (BMWi) (2019): Kommission “Wachstum, Strukturwandel und Beschäftigung"-Abschlussbericht. [Federal Ministry for Economic Affairs and Energy: Commission "Growth, Structural Change and Employment", German only]. Berlin. Available online: https://www.bmwi. de/Redaktion/DE/Artikel/Wirtschaft/kohleausstieg-und-strukturwandel.html (accessed on 16 July 2019). 
31. Bundesministerium für Wirtschaft und Energie (BMWi) (2019): Eckpunkte zur Umsetzung der strukturpolitischen Empfehlungen der Kommission „Wachstum, Strukturwandel und Beschäftigung“ für ein „Strukturstärkungsgesetz Kohleregionen“. [Federal Ministry for Economic Affairs and Energy: Cornerstones for the Implementation of the Recommendations of the Commission "Growth, Structural Change and Employment" for a "Structure Enhancement Law Coal Regions" German Only]. Available online: https://www.bmwi.de/Redaktion/DE/Downloads/E/eckpunkte-strukturwandel.html (accessed on 16 July 2019).

32. Federal Ministry for Economic Affairs and Energy (BMWi). Use of Nuclear Energy in Germany. 2019. Available online: https://www.bmwi.de/Redaktion/EN/Textsammlungen/Energy/uranium-and-nuclearenergy.html?cms_artId=255608 (accessed on 16 July 2019).

33. Hertwich, E.; de Larderel, J.A.; Arvesen, A.; Bayer, P.; Bergesen, J.; Bouman, E.; Gibon, T.; Heath, G.; Peña, C.; Purohit, P. (Eds.) UNEP (2016) Green Energy Choices: The Benefits, Risks and Trade-Offs of Low-Carbon Technologies for Electricity Production. Report of the International Resource Panel. Available online: http://www.un-expo.org/wp-content/uploads/2017/06/Green_energy_choices_The_benefits_risks_and_ trade-offs_of_low-carbon_technologies_for_electricity_production-2016UNEP_GEC_web.pdf.pdf (accessed on 14 July 2019).

34. Van der Voet, E.; Salminen, R.; Eckelman, M.; Mudd, G.; Norgate, T.; Hischier, R. UNEP (2013) Environmental Risks and Challenges of Anthropogenic Metals Flows and Cycles. A Report of the Working Group on the Global Metal Flows to the International Resource Panel. Available online: https:/orbit.dtu.dk/files/54666484/ Environmental_Challenges_Metals_Full_Report.pdf (accessed on 14 July 2019).

35. Francis, R.A. Socioecological Transitions and Land-Use Change. In Landscape Ecology; Fischer-Kowalski, M., Haberl, H., Eds.; Edward Elgar: Cheltenham, Gloucestershire, UK, 2008.

36. Bringezu, S. Visions of a sustainable resource use. In Sustainable Resource Management: Global Trends, Visions and Policies; Bringezu, S., Bleischwitz, R., Eds.; Greenleaf Publishing: Sheffield, UK, 2009; pp. 155-215. ISBN 978-1-906093-26-6.

37. Deilmann, C.; Effenberger, K.H.; Banse, J. Housing stock shrinkage: Vacancy and demolition trends in Germany. Build. Res. Inf. 2009, 37, 660-668. [CrossRef]

38. Gruhler, K.; Böhm, R. Auswirkungen des Demografischen Wandels auf das Stofflager und die Stoffflüsse des Wohngebäudebestands. Deutschland 2050; (Impacts of demographic change on material stocks and flows of residential buildings. Germany 2050); Fraunhofer IRB Verlag: Stuttgart, Germany, 2011; ISBN 978-3-8167-8452-4.

39. Müller, D.B. Stock dynamics for forecasting material flows-Case study for housing in The Netherlands. Ecol. Econ. 2006, 59, 142-156. [CrossRef]

40. Bergsdal, H.; Brattebø, H.; Bohne, R.A.; Müller, D.B. Dynamic material flow analysis for Norway's dwelling stock. Build. Res. Inf. 2007, 35, 557-570. [CrossRef]

41. IRP The International Resource Panel. 10 Key Messages on Climate Change; IRP The International Resource Panel: Paris, France, 2015.

42. Newbold, T.; Hudson, L.N.; Arnell, A.P.; Contu, S.; De Palma, A.; Ferrier, S.; Hill, S.L.L.; Hoskins, A.J.; Lysenko, I.; Phillips, H.R.P.; et al. Has land use pushed terrestrial biodiversity beyond the planetary boundary? A global assessment. Science 2016, 353, 288-291. [CrossRef] [PubMed]

43. MEA Millennium Ecosystem Assessment. Ecosystems and Human Well-Being: Synthesis; MEA Millennium Ecosystem Assessment: Córdoba, Argentina, 2005.

44. Díaz, S.; Settele, J.; Brondízio, E. Summary for Policymakers of the Global Assessment Report on Biodiversity and Ecosystem Services of the Intergovernmental Science-Policy Platform on Biodiversity and Ecosystem Services; IPBS: Bonn, Germany, 2019.

45. Bringezu, S.; Potočnik, J.; Schandl, H.; Lu, Y.; Ramaswami, A.; Swilling, M.; Suh, S. Multi-scale governance of sustainable natural resource use-Challenges and opportunities for monitoring and institutional development at the national and global level. Sustainibility 2016, 8. [CrossRef]

46. Chaudhary, A.; Pfister, S.; Hellweg, S. Spatially Explicit Analysis of Biodiversity Loss Due to Global Agriculture, Pasture and Forest Land Use from a Producer and Consumer Perspective. Environ. Sci. Technol. 2016, 50, 3928-3936. [CrossRef] 
47. Herrick, J.; Arnalds, O.; Bestelmeyer, B.; Bringezu, S.; Han, G.; Johnson, M.-V.; Kimiti, D.; Lu, Y.; Montanarella, L.; Pengue, W.; et al. UNEP (2016) Unlocking the Sustainable Potential of Land Resources: Evaluation Systems, Strategies and Tools. A Report of the Working Group on Land and Soils of the International Resource Panel. ISBN 978-92-807-3578-9. Available online: https://wedocs.unep.org/bitstream/handle/20.500. 11822/7708/-Unlocking_the_sustainable_potential_of_land_resources_Evaluating_systems,_strategies_and_ tools_Summary_for_policymakers-2016Unlocking_the_Sustainab.pdf?sequence=3\&isAllowed=y (accessed on 14 July 2019).

48. Bringezu, S.; Schütz, H.; Pengue, W.; O’Brien, M.; Garcia, F.; Sims, R.; Howarth, R.W.; Kauppi, L.; Swilling, M.; Herrick, J. UNEP (2014) Assessing Global Land Use: Balancing Consumption with Sustainable Supply. United Nations Environment Programme. p. 131, ISBN 978-92-807-3330-3. Available online: http://wedocs.unep.org/ bitstream/handle/20.500.11822/8861/assessing_global_land_use.pdf?sequence=1\&isAllowed=y (accessed on 14 July 2019).

49. O'Brien, M.; Schütz, H.; Bringezu, S. The land footprint of the EU bioeconomy: Monitoring tools, gaps and needs. Land Use Policy 2015, 47, 235-246. [CrossRef]

50. O'Brien, M.; Bringezu, S. What is a sustainable level of timber consumption in the EU: Toward global and EU benchmarks for sustainable forest use. Sustainibility 2017, 9, 812. [CrossRef]

51. Bringezu, S. Carbon Recycling for Renewable Materials and Energy Supply. J. Ind. Ecol. 2014, 18, 327-340. [CrossRef]

52. Hoppe, W.; Thonemann, N.; Bringezu, S. Life Cycle Assessment of Carbon Dioxide-Based Production of Methane and Methanol and Derived Polymers. J. Ind. Ecol. 2018, 22, 327-340. [CrossRef]

53. Mostert, C.; Bringezu, S. Measuring Product Material Footprint as New Life Cycle Impact Assessment Method: Indicators and Abiotic Characterization Factors. Resources 2019, 8, 61. [CrossRef]

54. Eurostat Material Flow Accounts Statistics-Material Footprints. Available online: https://ec.europa.eu/ eurostat/statistics-explained/index.php/Material_flow_accounts_statistics_-_material_footprints (accessed on 15 June 2019).

55. European Commission. COMMISSION REGULATION (EU) 2017/1505 of 28 August 2017 amending Annexes I, II and III to Regulation (EC) No 1221/2009 of the European Parliament and of the Council on the Voluntary Participation by Organisations in a Community Eco-Management and Audit Scheme. Available online: https://eur-lex.europa.eu/legal-content/EN/TXT/PDF/?uri=CELEX:32017R1505\&from=EN (accessed on 14 July 2019).

56. Cordell, D.; White, S. Sustainable Phosphorus Measures: Strategies and Technologies for Achieving Phosphorus Security. Agronomy 2013, 3, 86-116. [CrossRef]

57. Liu, J.; You, L.; Amini, M.; Obersteiner, M.; Herrero, M.; Zehnder, A.J.B.; Yang, H. A high-resolution assessment on global nitrogen flows in cropland. Proc. Natl. Acad. Sci. USA 2010, 107, 8035-8040. [CrossRef]

58. De Vries, W.; Kros, J.; Kroeze, C.; Seitzinger, S.P. Assessing planetary and regional nitrogen boundaries related to food security and adverse environmental impacts. Curr. Opin. Environ. Sustain. 2013, 5, 392-402. [CrossRef]

59. Egenolf, V.; Bringezu, S. Conceptualization of an Indicator System for Assessing the Sustainability of the Bioeconomy. Sustainability 2019, 11, 443. [CrossRef]

60. Science Based Targets. Available online: https://sciencebasedtargets.org/ (accessed on 14 July 2019).

61. r3.0 | Redesign for Resilience | Regeneration for a Green, Enclusive and Open Economie. Available online: https://www.r3-0.org/ (accessed on 14 July 2019).

62. Sustainable Development Goals Knowledge Platform. Available online: https://sustainabledevelopment.un. org/hlpf (accessed on 14 July 2019).

63. The World Economic Forum. Available online: https://www.weforum.org/ (accessed on 14 July 2019).

64. EEA. More From Less-Material Resource Efficiency in Europe; EEA Report 10/2016; European Environment Agency: Luxemburg, 2016.

65. European Commission Environment-Eco-Management and Audit Scheme (EMAS). Available online: http://ec.europa.eu/environment/emas/index_en.htm (accessed on 14 July 2019).

(C) 2019 by the author. Licensee MDPI, Basel, Switzerland. This article is an open access article distributed under the terms and conditions of the Creative Commons Attribution (CC BY) license (http://creativecommons.org/licenses/by/4.0/). 